\title{
Successful Treatment of Ulcers with Honey-Based Topical Preparation: Five Case Reports
}

\author{
Atefeh Naeimifar ${ }^{1}$, Behnaz Daneshmand ${ }^{2}$, Aniseh Samadi ${ }^{2}$, Zeinab Variji ${ }^{2}$ and Saman Ahmad Nasrollahi ${ }^{2 *}$ \\ ${ }^{1}$ Department of Pharmaceutics, Faculty of Pharmacy, Tehran University of Medical Sciences, Tehran, Iran \\ ${ }^{2}$ Center for Research \& Training in Skin Diseases \& Leprosy, Tehran University of Medical Sciences, Tehran, Iran
}

Submission: July 07, 2020; Published: July 20, 2020

*Corresponding author: Saman Ahmad Nasrollahi, Center for Research \& Training in Skin Diseases \& Leprosy, Tehran University of Medical Sciences, Iran

Abstract

Background and objectives: Ulcers are a global public health problem in the world, and expensive wound dressings are not universally available. Most wound patients suffer injuries that can be treated conservatively. However, the ideal dressing for the wound has not been identified. The aim of the study was to evaluate the changes in physical and morphological properties due to topical application of honey ointment on diabetic foot ulcers or cutaneous wounds. Methods: Honey ointment contained $40 \%$ honey in the lanoline base. Five patients of either sex were selected. Site of the wound, shape, size, and margin were recorded on day 0 and observed during weeks 2-3, and also to the end of healing to record the progression of granulation, scar type, shape, size, and clinical symptoms. Results: There was significant improvement in the healing process as formulation possesses antibacterial, wound cleansing, and wound healing properties. All patients showed significant improvement after 2-3 weeks with honey ointment. Conclusion: a combination of honey and lanolin may be effective in the treatment of low to moderate wounds.

Keywords: Honey; Lanoline; Wound Healing; Phenolic Compounds; Skin Moisturizer

\section{Introduction}

Wounds are the most common injuries seen throughout the world [1]. Some ulcers are not severe and can be handled outside the hospital to reduce both the cost and hospitalization time [2]. Previous studies have shown that using natural medicine is effective in healing wounds. These medicines are gaining popularity because of their widespread availability, showing fewer or no adverse effects, moderate efficacy, and low cost as compared with synthetic drugs [3]. The most common and traditional ingredient used for a skin ulcer is honey. The carbohydrate in honey and several phenolic compounds such as p-hydroxybenzoic acid, naringenin, pinocembrin, and chrysin are antimicrobials and antioxidants [4]. Another potential wound dressing ingredient is lanoline which has been used for a while as a skin moisturizer. The rationale behind using lanoline in the mixture is derived from the observation that it has emollient properties. Honey and lanoline are natural ingredients, comprising antioxidant, antibacterial, and antifungal compounds [5-7]. The current study set to objectively investigate the effectiveness of a semisolid formulation of honey in lanoline base to treat wounds.

\section{Materials and Methods}

Before-and-after design of study was conducted at the Skin Diseases \& Leprosy, Research \&\& Training Center of Tehran University of Medical Sciences from June to September 2017 to find out the effect of honey ointment on poor healing wounds. The patients provided informed consent to have their photographs published. All clinical cases are described in (Table 1). Before application of honey ointment on the wound on the first day, the wound was cleaned with normal saline; honey ointment was applied directly or on sterile cotton gauze, and the wound was dressed daily in the morning and evening.

\section{Results and Discussion}

The definitive observational evaluation (Figure 1 \& Table 1) confirmed that the wounds had been completely repaired. Wounds not only damage the cutaneous tissue locally, but also cause some systemic effects, such as loss of fluid and protein, sepsis, changes in the metabolic state, and involvement of the hematological and immune systems [8]. Despite the enormous evolution in 
science and technology, it is still difficult to improve the healing progression in a challenge to limit the length of hospitalization and suffering. The use of natural products such as honey to treat wounds has great appeal for people, especially, in underdeveloped countries [2]. There are a lot of evidence to support the benefits of honey dressing in reducing swelling and redness associated with wounds. The findings revealed that ointment (containing $40 \%$ honey) for diabetic wounds healed all patients. The outcome was indicative of successful wound healing during weeks 2-3 and controlled infection. Honey reduces the pain, edema, and has an antibacterial property due to its acidity, osmolality, hydrogen peroxide content, and stimulation of immunity [3]. Honey exerts direct nutrient effect on regeneration of tissue because it contains a wide range of amino acids, vitamins, and trace elements in addition to large quantities of readily assailable sugars. It promotes rapid healing as it stimulates tissue regeneration, angiogenesis, and fibroblast growth. Anti-inflammatory action of honey soothes healing by reducing pain and swelling. Further studies have shown that honey contains inhibin, an enzyme from bee pharyngeal glands, which breaks down to hydrogen peroxide and glucolactone/gluconic acid; these act as a mild disinfectant and mild antibiotic, respectively.

Table 1: Description of five clinical cases.

\begin{tabular}{|c|c|c|c|c|c|}
\hline Case & Age/sex & Disorder & Application & Duration & Result \\
\hline Patient 1 & $12 /$ male & chemical burning & $\begin{array}{l}\text { wound was washed with normal saline, and } \\
\text { then covered with sterile gauze dressing } \\
\text { twice a day }\end{array}$ & 7 days & $\begin{array}{l}\text { Controlled infection and edema, } \\
\text { reduce the size of wound }\end{array}$ \\
\hline Patient 2 & $50 /$ male & diabetic foot ulcer & $\begin{array}{c}\text { wound was washed with normal saline, and } \\
\text { then covered with sterile gauze dressing } \\
\text { three times a day }\end{array}$ & 10 days & $\begin{array}{l}\text { reduced the swelling and infection } \\
\text { associated with wound, soothed } \\
\text { healing }\end{array}$ \\
\hline Patient 3 & $40 /$ male & diabetic foot ulcer & $\begin{array}{c}\text { wound was washed with normal saline, and } \\
\text { then covered with sterile gauze dressing } 3 \\
\text { times a day }\end{array}$ & 14 days & $\begin{array}{l}\text { Partial clinical resolution of the foot } \\
\text { ulcer and infection disappeared }\end{array}$ \\
\hline Patient 4 & $32 /$ female & $\begin{array}{l}\text { burn caused by } \\
\text { hot water steam }\end{array}$ & $\begin{array}{l}\text { wound was washed with normal saline, and } \\
\text { then covered with sterile gauze dressing } \\
\text { twice a day }\end{array}$ & 3 days & $\begin{array}{l}\text { Improve healing process and reduc- } \\
\text { ing pain and inflammation. }\end{array}$ \\
\hline Patient 5 & $25 /$ male & $\begin{array}{l}\text { malodourous } \\
\text { and deterioration } \\
\text { wound on his } \\
\text { buttock }\end{array}$ & $\begin{array}{l}\text { wound was washed with normal saline, } \\
\text { and then covered with sterile gauze dress- } \\
\text { ing three times a day }\end{array}$ & 21 days & $\begin{array}{l}\text { Significant improvement was noted } \\
\text { and the wound was almost healed. }\end{array}$ \\
\hline
\end{tabular}

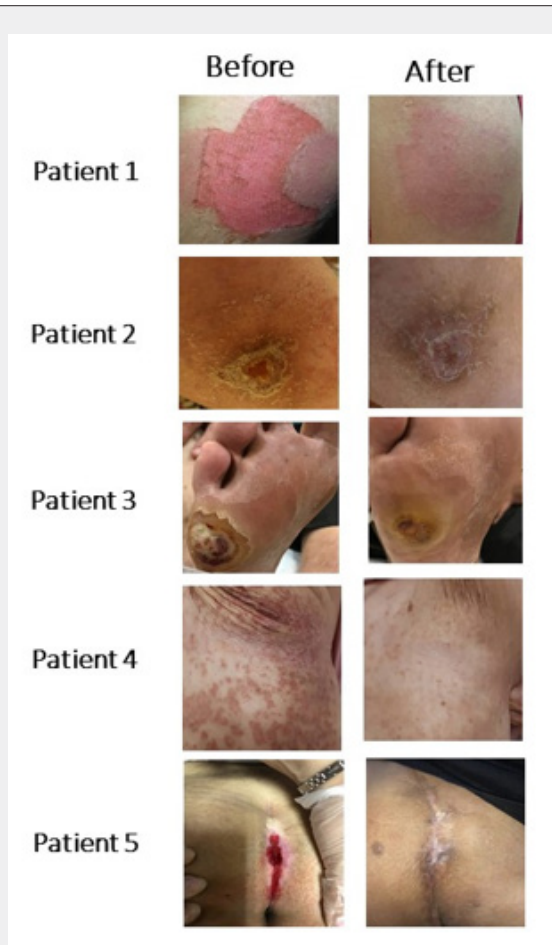

Figure 1: The patients before and after treatment by honey ointment. 
This $\mathrm{H}_{2} \mathrm{O}_{2}$ which is released at sufficient levels is effective against bacteria but does not cause tissue damaging, and fibroblast growth is stimulated by $\mathrm{H} 2 \mathrm{O} 2$ [9]. Acidic nature of honey releases oxygen as new growing cells need oxygen and stimulates the white blood cells. Honey has been used to heal wounds in many conditions. Two open-label trials also established significant wound healing with honey [10]. In another study, wound infections were cured with topical application of honey twice daily [6]. Two systematic reviews concluded that honey is valuable in the treatment of wounds $[11,12]$. Shukrimi $Q$ et al. showed the efficacy of honey dressing in reducing swelling and redness accompanied by less pain [13]. Hydration balance (moisture absorption and evaporation) is another important factor in wound healing. Wounds in moist conditions recover faster with less serious scar formation. Chvapil et al. revealed significant enhancement of the epithelization rate and the thickness of the dermis with respect to the effect of lanolin base alone [14]. The outcomes of the present study suggest that the combination of honey and lanolin may be effective in the treatment of low to moderate wounds associated with first and second-degree burns, diabetic foot ulcer, and topical irritations. This combination can be used in poor communities as it is inexpensive and affordable for their people.

\section{References}

1. Gurfinkel R, Palivatkel-Naim M, Gleisinger R, Rosenberg L, Singer AJ (2012) Comparison of purified olive oil and silver sulfadiazine in the treatment of partial thickness porcine burns. Am J Emerg Med 30(1): 79-83.

2. Mashreky SR, Rahman A, Chowdhury SM, Giashuddin S, Svanström L, et al. (2008) Burn injury: economic and social impact on a family. Public Health 122(12): 1418-1424.

3. Gray DC, Rutledge C (2013) Herbal supplements in primary care: patient perceptions, motivations, and effects on use. Holist Nurs Pract 27(1): 6-12.
4. Estevinho L, Pereira AP, Moreira L, Dias LG, Pereira E (2008) Antioxidant and antimicrobial effects of phenolic compounds extracts of Northeast Portugal honey. Food Chem Toxicol 46(12): 3774-3779.

5. Tuck KL, Hayball PJ (2002) Major phenolic compounds in olive oil: metabolism and health effects. J Nutr Biochem 13(11): 636-44.

6. Al-Waili NS, Saloom KY (1999) Effects of topical honey on postoperative wound infections due to gram positive and gram negative bacteria following caesarean sections and hysterectomies. Eur J Med Res 4(3): 126-30.

7. Al-Waili NS (2004) Investigating the antimicrobial activity of natural honey and its effects on the pathogenic bacterial infections of surgical wounds and conjunctiva. J Med Food 7(2): 210-222.

8. Moustafa A, Atiba A (2015) The Effectiveness of a Mixture of Honey, Beeswax and Olive Oil in Treatment of Canine Deep Second-Degree Burn. Glob Vet 14(2): 244-250.

9. McIntosh CD, Thomson CE (2006) Honey dressing versus paraffin tulle gras following toenail surgery. J Wound Care 15(3): 133-136.

10. Gethin G, Cowman S (2009) Manuka honey vs. hydrogel--a prospective, open label, multicentre, randomised controlled trial to compare desloughing efficacy and healing outcomes in venous ulcers. J Clin Nurs 18(3): 466-474.

11. Bardy J, Slevin NJ, Mais KL, Molassiotis A (2008) A systematic review of honey uses and its potential value within oncology care. J Clin Nurs 17(19): 2604-2623.

12. Moore OA, Smith LA, Campbell F, Seers K, McQuay HJ, et al. (2001) Systematic review of the use of honey as a wound dressing. BMC Complement Altern Med 1: 2-6.

13. Shukrimi A, Sulaiman AR, Halim AY, Azril A (2008) A comparative study between honey and povidone iodine as dressing solution for Wagner type II diabetic foot ulcers. Med J Malaysia 63(1): 44-46.

14. Chvapil M, Gaines JA, Gilman T(1988) Lanolin and epidermal growth factor in healing of partial-thickness pig wounds. J Burn Care Res 9(3): 279-84.

Your next submission with Juniper Publishers will reach you the below assets

- Quality Editorial service

- Swift Peer Review

- Reprints availability

- E-prints Service

- Manuscript Podcast for convenient understanding

- Global attainment for your research

- Manuscript accessibility in different formats ( Pdf, E-pub, Full Text, Audio)

- Unceasing customer service

Track the below URL for one-step submission

https://juniperpublishers.com/online-submission.php 